\title{
EFEK HIPNOSIS TEHADAP PERUBAHAN TEKANAN DARAH IBU HAMIL PREEKLAMPSIA
}

\author{
Siti Khuzaiyah ${ }^{1}$, Anies $^{2}$, Sri Wahyuni ${ }^{3}$ \\ Email: khuzaiyahpenulis@gmail.com \\ 1. STIKES Muhammadiyah Pekajangan Pekalongan, Jl.Raya Ambokembang No.8 \\ Kedungwuni Pekalongan +6285659676149 \\ 2. Universitas Diponegoro Semarang \\ 3. Poltekkes Kemenkes Semarang
}

\begin{abstract}
Abstrak:
Latar Belakang : Angka Kematian Ibu (AKI) di Indonesia masih tinggi. Salah satu penyebab AKI adalah Preeklampsia. Pada ibu preeklampsia terjadi peningkatan tekanan darah dan peningkatan kadar leukosit. Upaya penanganan preeklampsia saat ini masih bersifat medikamentosa, belum mengarah pada kompelemntary terapi seperti hipnosis. Hipnosis adalah suatu kondisi relaksasi dan komunikasi bawah sadar. Hipnosis telah terbukti bermanfaat secara psikologis maupun medis. Tujuan penelitian ini adalah untuk menganalisis pengaruh hipnosis terhadap perubahan tekanan darah ibu hamil preeklampsia di Wilayah Kerja Dinas Kesehatan Kabupaten Pekalongan.

Metode: jenis penelitian ini adalah Quasi Experiment dengan desain penelitian pretest-posttest control group. Subjek penelitian ini yaitu 32 ibu hamil preeklampsia yang terbagi dalam 2 kelompok yaitu kelompok kontrol dan kelompok perlakuan perawatan kehamilan standar. Hipnosis dilakukan sebanyak $3 \mathrm{x}$ terapi.

Hasil: ada perbedaan tekanan darah sebelum dan setelah hipnosis dengan $p$ vlaue sistolik 0,025 dan $\mathrm{p}$ value diastolik 0,002 . Ada perbedaan tekanan darah kelompok kontrol dan kelompok perlakuan setelah dilakukan hipnosis dengan $\mathrm{p}$ value sistolik 0,002 dan $\mathrm{p}$ value diastolik 0,013 . Penurunan tekanan darah setelah hipnosis mencapai $20 \mathrm{mmHg}$ (sistole) dan $7,5 \mathrm{mmHg}$ (diastole).

Simpulan: hipnosis berpengaruh terhadap penurunan tekanan darah pada ibu preeklampsia
\end{abstract}

Kata kunci:tekanan darah, hipnosis.

\section{Pendahuluan}

Angka Kematian Ibu (AKI) Indonesia berdasarkan Survey Demografi Kesehatan Indonesia (SDKI) tahun 1992 mencapai 390/100.000 kelahiran hidup, selanjutnya angka tersebut dapat ditekan terus sampai dengan 228 pada tahun 2007, sedangkan pada tahun 2012 mulai naik sampai dengan angka 359 per 100.000 kelahiran hidup. Target Millennium Development Goal (MDGs) menjadi 102/100.000 pada tahun 2015.Penyebab AKI di Jawa Tengah tahun 2012 sebanyak 26,09\% disebabkan oleh Hipertensi dan Preeklampsia, sedangkan pada tahun 2013 hipertensi dan preeklampsia mencapai $28 \% \quad 3$. Preeklampsia adalah suatu sindrom spesifik pada kehamilan yang terjadi setelah usia kehamilan 20 minggu, pada wanita yang sebelumnya normotensi. Keadaan ini ditandai oleh peningkatan tekanan darah $(\geq$ $140 / 90 \mathrm{mmHg}$ ) yang disertai oleh protein uria ${ }^{2}$.

Ada beberapa upaya untuk mengendalikan tekanan darah tinggi. Cara tersebut dapat bersifat medis maupun non medis. Salah satu upaya upaya non medis adalah dengan massage dan hipnosis. Metode ini dipilih karena kecilnya efek samping yang ditimbulkan. Hipnosis juga lebih aman, praktis dan lebih ekonomis dibandingkan dengan metode komplementer lain seperti musik/murotal dimana perlu alat untuk membunyikan murotal/musik dan perlu biaya untuk membeli alat tersebut. Selain itu, tidak semua orang suka akan musik tertentu dan belum tentu semua 
pasien tekanan darah tinggi beragama islam (Karen, et.all 2012 dan Gillian.et.all, 2009).

Hipnosis adalah suatu metode komunikasi yang efektif untuk memasukkan informasi atau ide baru ke dalam pikiran bawah sadar seseorang termasuk diri sendiri. Hipnosis mempunyai kelebihan dalam efektivitas berkomunikasi karena mampu membypass critical factor sehingga informasi atau sugesti lebih mudah masuk ke dalam pikiran bawah sadar (Adiyanto, 2010). Hipnosis telah terbukti secara medis bisa mengatasi berbagai macam gangguan psikologis maupun fisik ${ }^{9}$.

Pada tahun 2014, dari 35 kabupaten/kota di Provinsi Jawa Tengah, Kabupaten Pekalongan menduduki peringkat ke 7 jumlah kematian ibu terbanyak yaitu mencapai 29 kasus (Dinkes Jateng, 2014). Data Dinas Kesehatan Kabupaten Pekalongan menunjukkan bahwa AKI Tahun 2012 saat ini mencapai 184/100.000 kelahiran hidup (31 kasus), AKI Kabupaten Pekalongan menjadi 39 kasus pada tahun 2014, dimana penyebab kematian Ibu adalah Pre EklampsiaEklampsia sebanyak 16 kasus, perdarahan 8 kasus, infeksi 3 kasus, dan lain-lain sebanyak 12 kasus. Dari 16 kasus kematian karena Preeklampsia, 13 terjadi pada masa nifas dan 3 terjadi pada masa persalinan. (Dinkes Kab. Pekalongan, 2015).

Upaya-upaya yang sudah dilakukan oleh salah satu puskesmas di Kabupaten Pekalongan dalam menyikapi kematian ibu yang tinggi adalah dengan melaksanakan program Puskesmas mampu salin, kelas ibu hamil, kunjungan rumah ibu hamil resiko tinggi, penyuluhan kelompok ibu hamil resiko tinggi, penguatan rujukan, pendampingan $\mathrm{P} 4 \mathrm{~K}$ dan pelayanan Antenatal terpadu (Sulistyarini, 2015).Pada kasus ibu yang sudah terdeteksi resiko tinggi, termasuk diantaranya pada ibu yang menderita preeklampsia ringan, upaya yang dilakukan yaitu konsul dokter, kunjungan rumah untuk pemantauan tekanan darah setiap satu minggu sekali. Upaya yang mengarah ke dimensi psikologis dan spiritual saat ini belum ada (Sulistyarini, 2015). Penelitian Nugroho, dkk (2012) hipnoterapi mampu menurunkan tekanan darah dengan mean rank penurunan sistole 21,00 dan diastole 25,5. Penelitian Subandiyo (2014) membuktikan bahwa Pijat tenkuk dan hipnosis menurunkan tekanan darah, dengan nilai penurunan sistolik 15,62 $\mathrm{mmHg}$ dan diastolik $6,72 \mathrm{mmHg}$.

Penelitian Winarto terhadap klien hipertensi primer membuktikan bahwa hipnosis mampu menurunkan tekanan darah sistolik secara bermakna $17,6 \mathrm{mmHg}(\mathrm{p}=$ $0,001, \alpha=0,05$ ), sementara diastolik turun secara bermakna yaitu $10,21 \mathrm{mmHg}$ dengan $\mathrm{p}=0,000$ dan nilai $\alpha=0,05$.

\section{Metode Penelitian}

Jenis penelitian ini adalah quasi experimentdengan desainPretest-posttes with control group. Populasi dalam penelitian ini adalah ibu hamil dengan preeklampsia wilayah kerja Dinas Kesehatan Kabupaten Pekalongan tahun 2016. Tekhnik sampling adalah purpossive samplin dengan jumlah sampel 32 ibu hamil.

\section{Hasil dan Pembahasan}

A. Karakteristik Responden

Tabel 1 Karakteristik responden berdasarkan Umur, Gravida, Tingkat Pendidikan, Indeks Masa Tubuh, Umur Kehamilan dan Pekerjaan pada Kelompok Kontrol dan Kelompok Perlakuan di Wilayah Kerja Dinas Kesehatan Kabupaten Pekalongan 2016 


\begin{tabular}{|c|c|c|c|c|c|c|c|c|c|}
\hline No & Karakteristik & Mean & $\mathrm{SD}$ & Min & Max & $p$ value & Kategorik & $\mathrm{n}(\%)$ & $\mathrm{N}$ \\
\hline \multirow[t]{6}{*}{1} & Usia & & & & & \multirow{8}{*}{$0,817^{a}$} & & & \multirow{8}{*}{$\begin{array}{c}32 \\
(100 \%)\end{array}$} \\
\hline & Kelompok & & & & & & Usia sehat & & \\
\hline & Kontrol & 32,06 & 5,69 & 20 & 40 & & $(20-35$ th $)$ & $22(68,8)$ & \\
\hline & & & & & & & $\begin{array}{l}\text { Resiko } \\
\text { Tingoi }\end{array}$ & & \\
\hline & Kelompok & & & & & & $\begin{array}{l}\text { Tingg1 } \\
(<20 \text { th dan }\end{array}$ & & \\
\hline & Perlakuan & 31,56 & 6,39 & 21 & 42 & & $>35$ th $)$ & $10(31,2)$ & \\
\hline \multirow[t]{6}{*}{2} & Gravida & & & & & & & & \\
\hline & Kelompok & & & & & & & & \\
\hline & Kontrol & 2,81 & 1,72 & 1 & 6 & \multirow{4}{*}{$0,522^{b}$} & Primigravida & $11(34,4)$ & \multirow{4}{*}{$\begin{array}{c}32 \\
(100 \%)\end{array}$} \\
\hline & Kelompok & & & & & & & & \\
\hline & Perlakuan & 2,5 & 1,67 & 1 & 6 & & $\begin{array}{l}\text { Multigravida } \\
\text { Grande }\end{array}$ & $16(50)$ & \\
\hline & & & & & & & multipara & $5(16,6)$ & \\
\hline \multirow[t]{7}{*}{3} & Pendidikan & & & & & \multirow{6}{*}{$0,861^{\mathrm{c}}$} & & & \multirow{6}{*}{$\begin{array}{c}32 \\
(100 \%)\end{array}$} \\
\hline & Kelompok & & & & & & & & \\
\hline & $\begin{array}{l}\text { Kontrol } \\
\text { Kelompok }\end{array}$ & 7,87 & 2,66 & 6 & 12 & & SD & $20(62,5)$ & \\
\hline & Perlakuan & 7,81 & 3,06 & 6 & 17 & & SMP & $6(18,8)$ & \\
\hline & & & & & & & SMA & $5(15,6)$ & \\
\hline & & & & & & & PT & $1(31,1)$ & \\
\hline & Indeks Masa & & & & & & & & \\
\hline \multirow[t]{5}{*}{4} & Tubuh & & & & & \multirow{5}{*}{$0,627^{\mathrm{d}}$} & & & \multirow{5}{*}{$\begin{array}{c}32 \\
(100 \%)\end{array}$} \\
\hline & Kelompok & & & & & & & & \\
\hline & $\begin{array}{l}\text { Kontrol } \\
\text { Kelompok }\end{array}$ & 24,09 & 2,89 & 20 & 29 & & & & \\
\hline & Perlakuan & 23,51 & 3,8 & 19 & 29 & & & & \\
\hline & Umur & & & & & & & & \\
\hline \multirow[t]{4}{*}{5} & Kehamilan & & & & & \multirow{4}{*}{$0,498^{\mathrm{e}}$} & & & \multirow{4}{*}{$\begin{array}{c}32 \\
(100 \%)\end{array}$} \\
\hline & Kelompok & & & & & & & & \\
\hline & $\begin{array}{l}\text { Kontrol } \\
\text { Kelompok }\end{array}$ & 32,19 & 7,13 & 20 & 41 & & & & \\
\hline & Perlakuan & 33,75 & 5,67 & 20 & 40 & & & & \\
\hline \multirow[t]{4}{*}{6} & Pekerjaan & & & & & & & & \\
\hline & Kelompok & & & & & \multirow{3}{*}{$0,849^{\mathrm{f}}$} & Tidak & & \multirow{3}{*}{$\begin{array}{c}32 \\
(100 \%)\end{array}$} \\
\hline & Kontrol & & & & & & Bekerja/IRT & $12(37,5)$ & \\
\hline & Kelompok & & & & & & Pedagang & $3(9,4)$ & \\
\hline
\end{tabular}


Perlakuan

Buruh

Tekstil $\quad 16(50)$

Guru $\quad 1(3,1)$

Sumber: Data Primer Diolah

a. Independent sample t-test

b. Mann-whitney U test

c. Mann-whitnye U test

d. Independent sample t-tes

e. Independent sample t-test

f. Pearson Chi-square

1) Umur

Karakteristik responden berdasarkan umur menunjukkan bahwa rata-rata umur responden pada kelompok kontrol 32 tahun dengan usia minimal 20 tahun dan usia maksimal 40 tahun. Pada kelompok perlakuan, rata-rata usia responden 32 tahun dengan usia minimal 21 tahun dan usia maksimal 42 tahun. Berdasarkan distribusi frekuensi kategorik terdapat $22(68,8 \%)$ dan pada rentang usia 20-35 tahun, dan $10(31,2 \%)$ ada pada rentang usia resiko tinggi $(<25$ tahun dna $>35$ tahun).

Umur merupakan salah satu faktor yang menentukan status kesehatan ibu hamil. Akan tetapi pada kasus preklampsia umur tidak menjadi satusatunya faktor resiko kemunculan preeklampsia, melainkan ada faktor lain seperti nulipara, lingkungan, kondisi sosial ekonomi, seasonal influences, obesitas, kehamilan ganda, usia ibu, hiperhomocysteinemia, gangguan metbaolis dan preeklampsia pada kehamilan sebelumnya (Cunningham, 2014.h.731). Banyaknya preeklampsia yang terjadi pada rentang usia sehat dikarenakan proses kehamilan dan persalinan paling banyak terjadi pada usia produktif 20-35 tahun. Penelitian Khusen dan Polim (2012) juga menunjukkan bahwa rata-rata pasien preeklampsia yang meninggal ada pada rentang usia 20-39 tahun, dengan ratarata usia 28,2 tahun.

Namun demikian, adanya data yang menunjukkan bahwa hampir separuh responden preeklampsia berusia resiko tinggi juga harus diperhatikan. Usia ibu berkaitan erat dengan sistem kekebalan tubuh, fungsi sel, serta berkaitan dengan kemampuan ibu dalam memberikan nutrisi dan oksigenasi kepada janin yang dikandung. Sebagian masalah kesehatan adalah berkaitan dengan usia. Tekanan darah tinggi dan beberapa bentuk diabetes berkaitan dengan usia. Pada usia $>35$ tahun juga seorang wanita mempunyai kesempatan 5\% melahirkan bayi dengan kelainan kromosom (GB Curtis, 1997).

Usia resiko tinggi juga berkaitan dengan stress psikologis, hal ini sesuai juga dengan hasil wawancara kepada 10 responden dengan usia resiko tinggi, 6 orang $(60 \%)$ diantaranya mengatakan cemas dan takut dengan kehamilannya. Baratawidjaya \& Rengganis (2010) menyatakan bahwa pemicu lain resiko autoimun adalah stress psikologis dan faktor makanan. Sementara faktor toleransi mal adaptiv sistem imun (autoimun) antara ibu, placenta dan jaringan fetus menjadi salah satu penyebab preeklampsia disamping factor 
implantasi placenta yang tidak normal, mal adaptasi kardiovaskular dan faktor genetik (Cunnigham, 2014).

Fungsi sel dan sistem tubuh pada ibu pada rentang usia beresiko berbeda dengan ibu pada usia sehat. Kemampuan sel-sel untuk berubah (remodelling) pada awal kehamilan sangat penting agar plasentasi berjalan normal dan janin mendapat suplai oksigen secara cukup. Apabila pada saat kebutuhan metabolik unit fetoplasenta meningkat selama kehamilan, sementara itu arteriola spiralis tidak dapat mengakomodasi peningkatan aliran darah yang diperlukan, maka akan terjadi 'disfungis placenta' yang bermanifestasi klinis sebagai preeklampsia (Errol R Norwitz \& John O.Schorge, 2008, h.89 dalam Ekaputra, 2014). Terdapat hubungan umpan balik positif antara hipoksia dan plasentasi abnormal (Lunghi L, et.all; Redman CW, 2005 dalam Ekaputra, 2014).

2) Gravida

Karakteristik responden berdasarkan gravida menunjukkan bahwa rata-rata responden gravida 3 dengan minimal gravida 1 dan maksimal gravida 6 , sedangkan pada kelompok perlakuan menunjukkan rata-rata gravida kelompok perlakuan 3 dengan minimum gravida 1 dan maksimum gravida 6 . Berdasarkan distribusi frekuensi kategorik primigravida $11 \quad(34,4 \%)$, multigravida $16(50 \%)$ dan grande multipara $5(16,6 \%)$.

Cunningham (2014, h.713) menyebutkan bahwa faktor resiko preeklampsia adalah nulipara, lingkungan, kondisi sosial ekonomi, seasonal influences, obesitas, kehamilan ganda, usia ibu, hiperhomocysteinemia, gangguan metabolis dan preeklampsia pada kehamilan sebelumnya. Penelitian Kartikasari (2009) menyebutkan bahwa primigravida (nulipara) memiliki peluang sebesar 1,458 kali terkena preeklampsia dibandingkan dengan yang bukan primigravida. Karkata (2005) melakukan penelitian di RS Denpasar dan diperoleh data bahwa insiden preeklampsia pada primigravida $11,03 \%$. Penelitian Polim dan Khusen (2012) bahwa kasus kematian ibu dengan preeklampsia pada primipara mencapai $31,6 \%$.

3) Pendidikan

Karakteristik responden berdsarkan lama pendidikan, menunjukkan bahwa rata-rata lamanya pendidikan pada kelompok kontrol adalah 7,87 $\pm 2,66$, pendidikan minimal di 6 (SD) dan pendidikan tertinggi 12 (SMA). Sementara itu, lama pendidikan kelompok perlakuan rata-rata $7,81 \pm 3,06$, dengan lama paling sedikit 6 tahun (SD) dan lama pendidikan paling lama adalah 17 tahun (S1).

Tingkat pendidikan seseorang mempengaruhi bagaimana seorang mengambil keputusan atas masalah kesehatan yang dialaminya. Semakin rendah pendidikan ibu maka akan semakin sedikit keinginan memanfaatkan pelayanan kesehatan (Rukmini, 2005). Ibu dengan pendidikan tinggi dan yang bekerja di sektor formal mempunyai akses yang lebih baik terhadap informasi tentang kesehatan, lebih aktif menentukan sikap dan lebih mandiri mandiri mengambil tindakan perawatan (Padila, 2014).

4) Indeks Masa Tubuh (IMT)

Karakteristik responden berdasarkan IMT menunjukkan bahwa IMT pada kelompok kontrol 24,09 dengan IMT terendah 20 dan IMT tertinggi 29. Pada kelompok perlakuan rata-rata IMT 23,51 dengan IMT terendah 19 dan IMT tertinggi 29.

5) Umur Kehamilan 
Karakteristik responden berdasarkan umur kehamilan menunjukkan bahwa pada kelompok kontrol rata-rata umur kehamilan adalah 32,2 minggu dengan usia kehamilan paling muda 20minggu dan usia kehamilan paling tua adalah 41 minggu. Sedangkan pada kelompok perlakuan, rata-rata umur kehamilan 33,8 minggu dengan usia kehamilan paling muda 20 minggu dan usia kehamilan paling tua adalah 41 minggu. Umur kehamilan memiliki kaitan yang erat dengan preeklampsia. Preeklampsia adalah suatu sindrom spesifik pada kehamilan yang terjadi setelah usia kehamilan 20 minggu, pada wanita yang sebelumnya normotensi. Proteinuria hanya timbul setelah kehamilan 20 minggu (Cunningham, et.all, 2010, p.706). Begitu juga dengan beberapa penanda lain preeklampsia juga mulai muncul setelah kehamilan memasuki 20minggu. Penanda tersebut meliputi: penurunan VEGF \& TGF beta, peningkatan EC disfunction, peningkatan ET-1 \& pengeluaran IL 6, peningkatan produksi cytokin dan peningkatan aktivasi leukosit (Rahma W dan Ahmed A, 2011). Berdasarkan karakteristik umur kehamilan responden, maka dapat dipastikan bahwa tekanan darah tinggi yang dialami oleh responden adalah benar karena preeklampsia karena smeua terjadi pada usia $\geq 20$ minggu. Karakter responden juga menunjukkan bahwa tidak ada responden yang memiliki umur kehamilan posterm ( $>40$ minggu).

6) Pekerjaan
Karakteristik responden berdasarkan pekerjaan menunjukkan bahwa $16(60 \%)$ responden bekerja sebagai buruh tekstil dan $12(37,5 \mathrm{mmHg})$ ibu yang tidak bekerja

Hasil analisis menunjukkan bahwa paling banyak penderita preeklampsia bekerja sebagai buruh tekstil. Berdasarkan interview kepada responden, mereka menyebutkan bahwa jenis-jenis pekerjaan sebagai buruh tekstil meliputi bagian penjahitan, pengepakan, pemotongan benang-benang, dan melipat tekstil. Informasi dari responden menyebutkan bahwa kondisi pabrik tekstil tempat mereka bekerja memiliki pencemaran udara terutama saat pagi jadwal pembuangan limbah. Jenis-jenis pencemaran yang mereka dapatkan adalah asap sisa pembakaran batubara pabrik, sisa benang yang beterbangan di udara dan debu-debu di udara sementara mereka tidak memakai masker. Cunningham (2014) menyebutkan faktor resiko preeklampsia meliputi usia, nulipara, lingkungan, kondisi sosial ekonomi, seasonal influences, obesitas, kehamilan ganda, usia ibu, hyperhomocysteinemia, gangguan metabolis dan preeklampsia pada kehamilan sebelumnya. Lingkungan berperan dalam autoimunitas seperti kemiripan molekuler dan infeksi, hormon, obat, radiasi UV, logam, oksigen dan radikal bebas. Bentuk lain dari kerusakan fisis dapat mengubah imunigenesitas self antigen terutama kerusakan self molekul oleh radikal bebas oksigen yang menimbulkan sebagian proses inflamasi.

Pekerjaan juga terkait dengan stress seseorang. Ibu bekerja memiliki peluang stress lebih besar dibanding ibu tidak bekerja. Baratawidjaya (2010) menjelaskan bahwa pemicu autoimun lainnya adalah stress psikologis dan faktor makanan. 
B. Analisis Multivariat

Pada analisis regresi pada variabel hipnosis, usia kehamilan, IMT, pendidikan, gravida dan umur terhadap tekanan darah sistolik pada kolom best model hanya terdapat variabel hipnosis yang mempengaruhi tekanan darah sistolik dengan $p$ value 0,025 dan nilai coefficient 23,187, artinya dengan hipnosis akan mengurangi tekanan darah sistolik.Pada analisis regresi pada variabel hipnosis, usia kehamilan, IMT, pendidikan, gravida dan umur terhadap tekanan darah sistolik pada kolom best model hanya terdapat variabel hipnosis yang mempengaruhi tekanan darah sistolik dengan $p$ value 0,010 dan nilai coefficient $-13,625$, artinya dengan hipnosis akan mengurangi tekanan darah diastolik

C. Perbedaan Tekanan Darah Pre dan Post pada Kelompok Kontrol dan Perlakuan

Tabel 2. Perbandingan Tekanan Darah pre dan post pada kelompok kontrol dan kelompok perlakuan di wilayah kerja Dinas Kesehatan Kabupaten Pekalongan $2016(\mathrm{~N}=32)$.

\begin{tabular}{|c|c|c|c|c|c|c|c|c|c|}
\hline \multirow[t]{2}{*}{ No } & \multirow{2}{*}{$\begin{array}{c}\text { Variabel } \\
\text { Tekanan } \\
\text { Darah }\end{array}$} & \multicolumn{2}{|c|}{ Pre } & \multicolumn{2}{|c|}{ Post } & \multicolumn{3}{|c|}{ Perubahan Tekanan Darah } & \multirow{2}{*}{$\begin{array}{l}\text { Pre- } \\
\text { post } \\
\text { Value }\end{array}$} \\
\hline & & $\begin{array}{l}\text { Mean } \pm \\
\text { SD }\end{array}$ & $\begin{array}{l}\text { Min- } \\
\text { Mak }\end{array}$ & $\begin{array}{l}\text { Mean } \pm \\
\text { SD }\end{array}$ & $\begin{array}{l}\text { Min- } \\
\text { Mak }\end{array}$ & Turun & Naik & Tetap & \\
\hline \multirow{4}{*}{1} & Kelompok & & & & & & & & \multirow{4}{*}{$0,059^{a}$} \\
\hline & Kontrol & & & & & & & & \\
\hline & Sistole & $\begin{array}{c}155,31 \pm \\
27,415\end{array}$ & $\begin{array}{c}130- \\
240\end{array}$ & $\begin{array}{c}150,06 \pm \\
36,852\end{array}$ & $\begin{array}{l}86- \\
245\end{array}$ & $\begin{array}{c}9 \\
(56,3 \%)\end{array}$ & $\begin{array}{c}2 \\
(12,5 \%)\end{array}$ & $5(31,3)$ & \\
\hline & Diastole & $\begin{array}{c}95,5 \pm \\
15,535\end{array}$ & $\begin{array}{l}80- \\
140\end{array}$ & $\begin{array}{l}95,5 \pm \\
15,535\end{array}$ & $\begin{array}{l}80- \\
140\end{array}$ & $\begin{array}{c}6 \\
(37,5 \%)\end{array}$ & $0(0 \%)$ & $\begin{array}{c}10 \\
(62,5 \%)\end{array}$ & \\
\hline \multirow[t]{3}{*}{2} & $\begin{array}{l}\text { Kelompok } \\
\text { Perlakuan }\end{array}$ & & & & & & & & \\
\hline & Sistole & $\begin{array}{c}146,88 \pm \\
13,889\end{array}$ & $\begin{array}{c}130- \\
170\end{array}$ & $\begin{array}{c}126,88 \\
\pm \\
13,765\end{array}$ & $\begin{array}{c}106- \\
160\end{array}$ & $\begin{array}{c}15 \\
(93,8 \%)\end{array}$ & $0(0 \%)$ & $\begin{array}{c}1 \\
(6,3 \%)\end{array}$ & \multirow[t]{2}{*}{$0,025^{\circ}$} \\
\hline & Diastole & $\begin{array}{c}92,50 \pm \\
7,746\end{array}$ & $\begin{array}{l}80- \\
100\end{array}$ & $\begin{array}{r}81,88 \pm \\
12,230\end{array}$ & $\begin{array}{l}60- \\
100\end{array}$ & $\begin{array}{c}13 \\
(81,3 \%)\end{array}$ & $\begin{array}{c}1 \\
(6,3 \%)\end{array}$ & $\begin{array}{c}2 \\
(12,5 \%)\end{array}$ & \\
\hline
\end{tabular}

- Wilcoxon Signed Rank Test

- Wilcoxon Signed Rank Test

- Paired Sample T-test

- Wilcoxon Signed Rank Test

Tabel 2 menunjukkan bahwa rata-rata tekanan darah pada kelompok kontrol, sistole pre yaitu $155 \mathrm{mmHg}$ dengan tekanan darah terendah yaitu $130 \mathrm{mmHg}$ dan tekanan darah tertinggi $240 \mathrm{mmHg}$, sedangkan rata-rata tekanan darah diastole pre perlakuan adalah 95,5 $\mathrm{mmHg}$ dengan tekanan darah terendah $90 \mathrm{mmHg}$ dan tekanan darah tertinggi 140 $\mathrm{mmHg}$. Tekanan darah post pada sistole ratarata sebesar $150 \mathrm{mmHg}$ dengan kadar tekanan darah terendah $86 \mathrm{mmHg}$ dan tekanan darah tertingi $245 \mathrm{mmHg}$, sedangkan pada diastole rata-rata tekanan darah adalah $95,5 \mathrm{mmHg}$ dengan tekanan darah terendah $80 \mathrm{mmHg}$ dan tekanan darah tertinggi adalah $140 \mathrm{mmHg}$.

Pada kelompok perlakuan, rata-rata tekanan darah sistole pre (sebelum hipnosis) yaitu $147 \mathrm{mmHg}$ dengan tekanan darah terendah

yaitu $130 \mathrm{mmHg}$ dan tekanan darah tertinggi $170 \mathrm{mmHg}$, sedangkan rata-rata tekanan darah diastole pre perlakuan adalah $92,5 \mathrm{mmHg}$ dengan tekanan darah terendah $90 \mathrm{mmHg}$ dan tekanan darah tertinggi $100 \mathrm{mmHg}$. Tekanan darah post perlakuan pada sistole rata-rata sebesar $127 \mathrm{mmHg}$ dengan tekanan darah terendah $106 \mathrm{mmHg}$ dan tekanan darah tertingi $160 \mathrm{mmHg}$, sedangkan pada diastole rata-rata tekanan darah adalah $80 \mathrm{mmHg}$ dengan tekanan darah terendah $60 \mathrm{mmHg}$ dan tekanan darah tertinggi adalah $100 \mathrm{mmHg}$

D. Perbedaan Tekanan Darah antara Kelompok Kontrol dan Kelompok Perlakuan

Tabel 3. Perbedaan tekanan darah pada 
kelompok kontrol dan kelompok perlakuan di Wilayah Kerja Dinas Kesehatan Kabupaten Pekalongan 2016

\begin{tabular}{llll}
\multicolumn{4}{c}{ Kesehatan Kabupaten Pekalongan 2016} \\
\hline & $\mathrm{N}$ & $z$ & $p$ value \\
\hline $\begin{array}{l}\text { Sistole } \\
\text { kelompok } \\
\text { kontrol- } \\
\text { kelompok }\end{array}$ & & & \\
perlakuan & 32 & $-3,029^{\mathrm{a}}$ & $0,002^{a}$ \\
$\begin{array}{l}\text { Diastole } \\
\text { kelompok }\end{array}$ & & & \\
$\begin{array}{l}\text { kontrol- } \\
\text { kelompok }\end{array}$ & & & \\
perlakuan & 32 & $-2,495^{\mathrm{b}}$ & $0,013^{b}$ \\
\hline
\end{tabular}

- Mann Whitney U Test

- Mann whitney U Test

Tabel 3 menunjukkan bahwa nilai signifikansi tekanan darah antara kelompok kontrol dan perlakuan lebih kecil dari nilai alpha $(0,05)$ yaitu sistole 0,002 dan diastole 0,013 . Dengan demikian ada perbedaan secara signifikan rata-rata skor tekanan darah pada kelompok kontrol dan kelompok perlakuan sebelum dan setelah intervensi hipnosis

E. Perbedaan Tekanan Darah Pre dan Post pada Kelompok Kontrol dan Perlakuan

Hipnosis memberikan pengaruh positif terhadap penurunan tekanan darah ibu hamil preeklampsia.Hipnosis merupakan metode komunikasi efektif yang mempunyai kelebihan dalam efektivitas komunikasi karena mampu membypass criticalfactor sehingga informasi atau sugesti lebih mudah masuk ke dalam pikiran bawah sadar (Adiyanto, 2010). Hipnosis telah terbukti secara medis bisa mengatasi berbagai macam gangguan psikologis maupun fisik (Majid, 2013 dan Wong, 2009). Hipnosis memberikan efek penurunan tekanan darah melalui tahapan relaksasi, aktivasi saraf para simpatik, penurunan aktivitas kardiovaskular, peningkatan vasodilatasi, peningkatan VEGf, menurunkan SFlt-1 pada plasma dan menurunkan tekanan darah. Efek penurunan tekanan darah ini sejalan dengan penelitian Nugroho, dkk (2012) yang menjelaskan bahwa hipnoterapi mampu menurunkan tekanan darah dengan mean rank penurunan sistole 21,00 dan diastole 25,5. Peneliti lain Subandiyo (2014) membuktikan bahwa Pijat tengkuk dan hipnosis menurunkan tekanan darah, dengan nilai penurunan sistolik 15,62 $\mathrm{mmHg}$ dan diastolik $6,72 \mathrm{mmHg}$.Pada proses hipnosis peneliti memposisikan ibu hamil responden dengan berbaring miring kiri, perut diganjal bantal kecil dan antar kaki diganjal bantal. Posisi ini memberikan efek maksimal pada penurunan tekanan darah. Hal ini sesuai dengan penjelasan bahwa pada posisi berbaring tekanan darah seseorang akan lebih rendah (Gunawan, Iany, 2010). Tidur miring ke kiri memberi keuntungan untuk ibu dan bayi, bayi akan mendapatkan aliran darah dan nutrisi maksimal ke plasenta karena vena besar (vena cava inferior) di belakang sebelah kanan spina mengembalikan aliran darah tubuh bagian bawah ke jantung.

Dari penelitian ini dapat disimpulkan bahwa hipnosis mampu menurunkan tekanan darah sistole dan diastole pada pasien preeklampisa sehingga dapat mengurangi resiko kematian ibu akibat preeklampsia. Rata-rata penurunan sistole mencapai $20 \mathrm{mmHg}$ dan penurunan diastole mencapai $7,5 \mathrm{mmHg}$

\section{Daftar Pustaka}

[1] Adiyanto, Lelik, 2009, Smartbirthing: Panduan Praktis Hipnosis Bagi Kehamilan dan Persalinan, UNDIP Pers

[2] Cunningham FG, Leveno KJ, Bloom SL, Hauth JC, Rause DJ, Spancy CY. Williams obstetrics. 23 ed. New York: Mc Graw Hill; 2010. p.706-47.

[3] Dinas Kesehatan Provinsi Jawa Tengah, 2014, ARAH DAN KEBIJAKAN PEMBANGUNAN KESEHATAN PROVINSI JAWA TENGAH, Makalah disampaikan 
pada Pelatihan Pengendali Diklat Jawa Tengah 2014

[4] Depkes RI, tanpa tahun, Upaya Percepatan Penurunan Angka Kematian Ibu dan Bayi Baru Lahir di Indonesia, avaiable on http://www.gizikia.depkes.go.id/artik el/upaya-percepatan-penurunanangka-kematian-ibu-dan-bayi-barulahir-di-indonesia/?print=print

[5] Dinkes Kabupaten Pekalongan. 2014. Rekapitulasi Data Kematian Ibu Dinas Kesehatan Kabupaten Pekalongan.

[6] Dinkes Kabupaten Pekalongan. 2015. Lokakarya Program EMAS; BERSINERGI TURUNKAN ANGKA KEMATIAN IBU. Available on http://www.pemkabpekalongan.go.id access on 10 Juni 2015

[7] Ekaputra, VG. 2014, Perbedaan Kadar Soluble Endoglin Serum dan Ekspresi Endoglin Placenta pada Preeklampsia / eklampsia dan Kehamilan Normotensi. Program Pendidikan Dokter Spesialis 1 Obstetri \& Ginekologi Fakultas Kedokteran Universitas Diponegoro Semarang.

[8] Husen, D \&Polin, A. 2012. Factors Influencing Maternal Mortality from Severe Preeclampsia and Eclampsia.MajObstetGinekolog Indonesia 2012; 36-2: 90-4

[9] Majid, Indra, E-Book Mengenal Hipnotis Modern, dalam http:www.indramajid.com/ www.masterhipnotis.com tanggal 14 Agustus 2013

[10] Naito A, Laidlaw TM, Henderson DC, Farahani L, Dwivedi P, Gruzelier JH.2003. The impact of self-hypnosis and Johrei on lymphocyte subpopulations at exam time: a controlled study. Brain Res Bull. 2003 Dec 30;62(3):241-53. [
[11] Posisi Tidur yang Baik Selama Hamil. Available on http://www.bidanku.com

[12] Rahma W, Ahmed A. Is inflammation the cause of preeclampsia? Biochem Soc Trans[internet]. 2011 [updated 2011 Des 1; cited 2013 May 28]; 39(6): 1619-27. Available from: http://www.ncbi.nlm.nih.gov/pmc/art icles/PMC3222326/

[13] Rukmini, Pengaruh Peran Karakteristik Ibu terhadap Persalinan Patologi, 2005

[14] Sherwood, Lauralee. 2011. Fisiologi Manusia dari Sel ke Sistem (Human Physiology; from cell to systems).p.766-767. Jakarta, EGC.

[15] Sholeh, 2007, Tahajud Menyembuhkan Berbagai Penyakit, Hikmah, Jakarta

[16] Subandiyo, 2013, Pengaruh Pijat Tengkuk dan Hipnotis terhadap Penurunan Tekanan darah pada Pasien Hipertensi, Tesis Program Studi Magister Epidemiologi Konsentrasi Sains Terapan Kesehatan, ProgramPAscasarjana Universitas Diponegoro

[17] Sulistyarini, 2015. Wawancara langsung dengan narasumber (bidan koordinator) Puskesmas kedungwuni II Kabupaten Pekalongan

[18] Wikstrom, A, 2007, Biochemical and Epidemiological Studies of Early Onset and Late Onset Preeclampsia. Digital Comprehensive Summaries of Uppsala Disertation of Faculty Medicine 